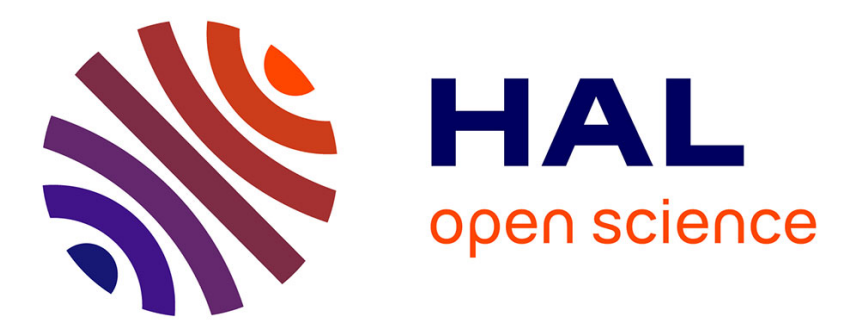

\title{
Isoderivative of deleted chromosome 20 in primary myelofibrosis (PMF) characterized by molecular cytogenetics and array CGH
}

\author{
N. Douet-Guilbert, J. Andrieux, J. L. Laï, P. Morice, J. L. Demory, A. \\ Basinko, V. Ugo, N. Gueganic, M. J. Bris, F. Morel, et al.
}

\section{To cite this version:}

N. Douet-Guilbert, J. Andrieux, J. L. Laï, P. Morice, J. L. Demory, et al.. Isoderivative of deleted chromosome 20 in primary myelofibrosis (PMF) characterized by molecular cytogenetics and array CGH. Annals of Hematology, 2009, 88 (11), pp.1157-1159. 10.1007/s00277-009-0753-3 . hal-00535061

\section{HAL Id: hal-00535061 https://hal.science/hal-00535061}

Submitted on 11 Nov 2010

HAL is a multi-disciplinary open access archive for the deposit and dissemination of scientific research documents, whether they are published or not. The documents may come from teaching and research institutions in France or abroad, or from public or private research centers.
L'archive ouverte pluridisciplinaire HAL, est destinée au dépôt et à la diffusion de documents scientifiques de niveau recherche, publiés ou non, émanant des établissements d'enseignement et de recherche français ou étrangers, des laboratoires publics ou privés. 


\title{
Isoderivative of deleted chromosome 20 in primary myelofibrosis (PMF) characterized by molecular cytogenetics and array CGH
}

\author{
N. Douet-Guilbert • J. Andrieux • J. L. Laï • P. Morice • \\ J. L. Demory • A. Basinko • V. Ugo • N. Gueganic • \\ M. J. Le Bris • F. Morel • M. De Braekeleer
}

Received: 16 March 2009/Accepted: 30 April 2009/Published online: 15 May 2009

(C) Springer-Verlag 2009

\begin{abstract}
Dear Editor,
Primary myelofibrosis (PMF) is a $B C R$ - $A B L$-negative chronic myeloproliferative disorder. Chromosomal abnormalities are heterogeneous but deletion of the long arm of chromosome $20(\mathrm{del}(20 \mathrm{q}))$ is a recurrent abnormality observed in 20-30\% in PMF [1]. A variant of deletion 20q, an isochromosome of the long arm of chromosome 20 with loss of interstitial material (ider(20q)), has recently been described in myeloid hemopathy [2-6]. To our knowledge, a sole case of primary myelofibrosis with ider(20q) has been published [7]. Here, we report two further cases.

Patient 1 is a 79-year-old-woman who presented with chronic leukoneutropenia. Physical examination revealed
\end{abstract}

N. Douet-Guilbert · A. Basinko · N. Gueganic · F. Morel · M. De Braekeleer

Laboratoire d'Histologie, d'Embryologie et de Cytogénétique,

Faculté de Médecine et des Sciences de la Santé,

Université de Brest,

Brest 29238, France

N. Douet-Guilbert • A. Basinko $\cdot$ M. J. Le Bris $\cdot$ F. Morel •

M. De Braekeleer

Laboratoire de Cytogénétique,

Centre Hospitalier Universitaire de Brest,

Brest 29609, France

N. Douet-Guilbert $\cdot$ V. Ugo $\cdot$ F. Morel $\cdot$ M. De Braekeleer

INSERM U613, Brest 29200, France

J. Andrieux · J. L. Laï

Laboratoire de Génétique Médicale, Hopital Jeanne de Flandre,

Centre Hospitalier Régional Universitaire de Lille,

Lille 59000, France neither hepatosplenomegaly nor lymphadenopathy. Trephine biopsy sections showed reticulin and collagen fibrosis with decreased cellularity. In fibrous tissue, megakaryocytes were dysplastic; granulocytic and erythroid lineages were nonexistent. An abdominal ultrasonography revealed a splenomegaly of $15.5 \mathrm{~cm}$. JAK2 ${ }^{\mathrm{V} 617 \mathrm{~F}}$ mutation was present. A diagnosis of primary myelofibrosis was made. Six months later, no sign of clinical evolution was observed. During these 6 months, the patient benefited from clinical surveillance, with blood parameters remaining stable.

Hepatosplenomegaly was found at physical examination of a 71 year-old-woman (patient 2). The bone marrow aspirate revealed reticulin fibrosis. The patient received

P. Morice

Service de Pneumologie 4 et d'allergologie,

Centre Hospitalier Pierre Le Damany,

Lannion 22303, France

\section{J. L. Demory}

Département d'Hématologie, Hopital St-Vincent de Paul, GHICL, Lille 59000, France

V. Ugo

Laboratoire d'Hématologie Biologique,

Centre Hospitalier Universitaire de Brest,

Brest 29609, France

M. De Braekeleer $(\square)$

Laboratoire de Cytogénétique,

Faculté de Médecine et des Sciences de la Santé,

Université de Brest, 22, avenue Camille Desmoulins, CS 93837, 29238 Brest, France

e-mail: marc.debraekeleer@univ-brest.fr 
blood transfusions during 1 year, before being lost to follow-up.

Cytogenetic analysis was performed on bone marrow cells at the time of diagnosis for both patients. All 20 metaphases observed after R-banding showed a 46,XX,ider(20)(q10) del (20)(q11q13) for patient 1. For patient 2, conventional analysis after G-banding revealed a 46,XX,del(20)(q11) in four metaphases only.

Metaphase and interphase fluorescent in situ hybridization (FISH) was performed using LSI D20S108 (20q12) SpectrumOrange probe (Abbott diagnostic, Rungis, France), CEP20 (Qbiogene, Illkirch, France), and TelVysion 20p and 20q probes (Abbott). Breakpoint localization was delineated with an appropriate set of bacterial artificial chromosome (BAC) clones, as previously described $[6,8]$.

For patient 1, LSI D20S108 was deleted. FISH studies showed absence of $20 \mathrm{p}$ subtelomeric probe and two copies of $20 \mathrm{q}$ subtelomeric probe in all analyzed metaphases. The isoderivative chromosome 20 was found to be dicentric. Interphase FISH studies did not show the presence of a clone with deletion $20 \mathrm{q}$ associated with the isoderivative clone. FISH was not performed in patient 2 because of scarcity of metaphases in the medullar sample.

Detection of gene copy number was performed by array comparative genomic hybridization (CGH) experiments following standard and manufacturer's recommendations (Agilent $^{\mathrm{TM}}$, Agilent Technologies, Santa Clara, CA, USA) using 44000 oligo probes approximately spaced at $40-100-\mathrm{kb}$ intervals across the genome. A duplication of the regions 20 cen $\rightarrow 20 \mathrm{q} 11.21$ and $20 \mathrm{q} 13.2 \rightarrow 20 \mathrm{qter}$ was identified by array CGH. This technique also revealed the same proximal breakpoint on the long arm of chromosome 20, in band 20q11.21, for both patients. Distal breakpoints were located in band 20q13.2, at $300 \mathrm{~kb}$ apart from each other (Fig. 1a). No additional copy number variation was observed in each case.

Based on array CGH and FISH results, the karyotype could then be rewritten for patients 1 and 2 as 46,XX,idic (20)(p11)del(20)(q11.21q13.2) and 46,XX,ider(20)(q10)del (20)(q11.21q13.2), respectively.

Located between KIF3B and DNMT3B genes (Fig. 1b), the proximal breakpoint observed in both patients is different from the recurrent breakpoint described in myelo-

Fig. 1 Breakpoint location for the two patients and genomic variations of chromosome 20. a Array CGH profile of isoderivative of deleted chromosome 20. The graphic shows the deleted regions on the short arm of chromosome 20 and the long arm of chromosome 20 (green arrows) and the proximal and the distal duplicated regions (red arrows). The dotted line represents breakpoints. b Representation of the proximal breakpoints (dotted line) on the long arm of chromosome 20 for patients 1 and 2, by array CGH and FISH with BACs. Applied BAC clones are bordered; candidate genes are surrounded. $\mathbf{c}$ Representation of the distal breakpoints (dotted lines) on the long arm of chromosome 20 for patients 1 and 2, by array CGH and FISH with BACs. Applied BAC clones are bordered; candidate genes are surrounded dysplastic syndrome with ider(20q) [6]. Distal breakpoints on the long arm of chromosome 20 were located in band 20q13.2 within a $340-\mathrm{kb}$ segment, containing the $A T P 9 A$ (which protein function is unknown) and SALL4 (a zinc finger transcription factor) genes (Fig. 1c). In patient 2, the distal breakpoint disrupted the NFATC2 gene, a member of the nuclear factor of activated $\mathrm{T}$ cell family.

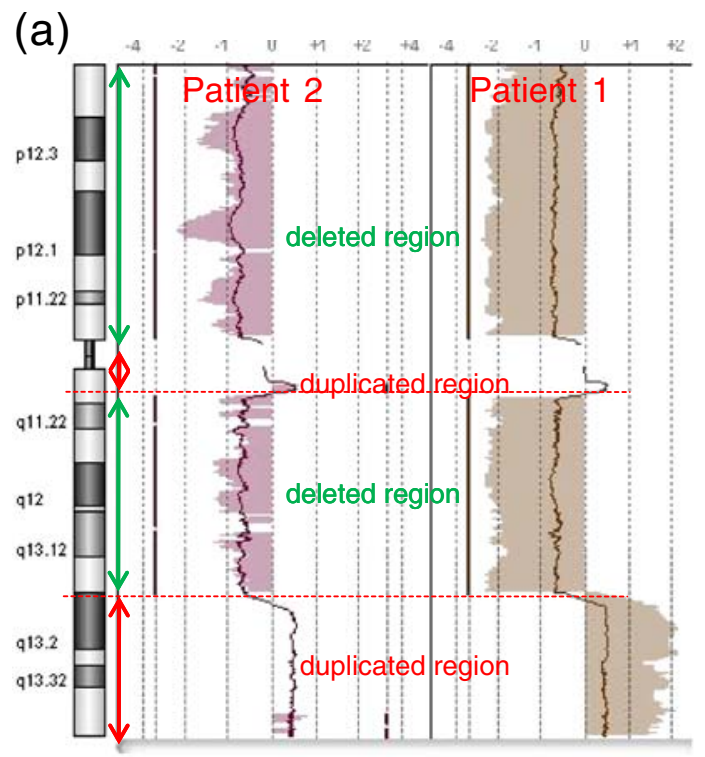

(b)

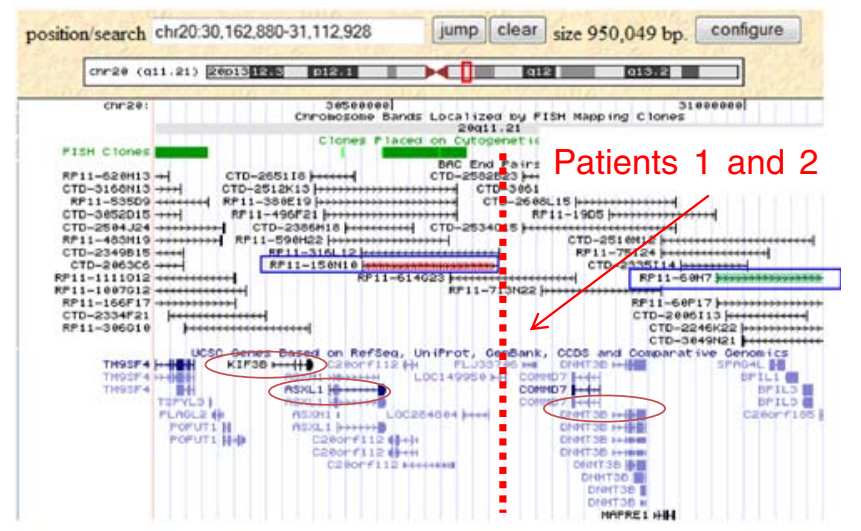

(c)

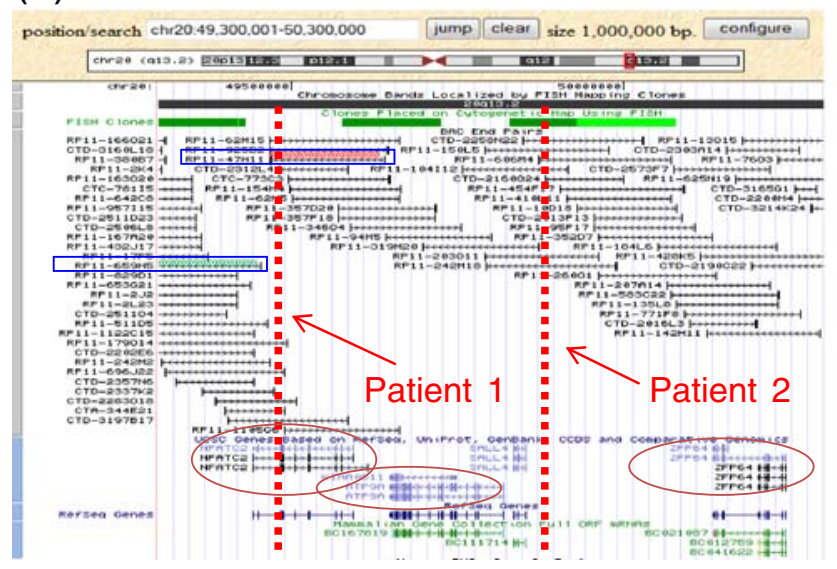


Located in the duplicated region, the KIF3B gene, encoding for a protein involved in chromosome movement during mitosis and meiosis, and the $A S X L 1$ gene, described in drosophila enhancing or repressing transcription of contiguous genes, were situated near the breakpoint. ZFP64 encodes for a zinc finger protein which function is unclear [5]. The intrachromosomal rearrangement on the long arm could produce a new chimeric gene or modify the expression of genes by connection of KIF3B, ASXL1, NFATC2, and ZFP64 genes.

As in del(20q), candidate genes contained in the deleted region of the long arm of chromosome 20 are suggested but, at present, the target genes remain unknown [6]. Near the proximal breakpoint, the DNMT3B gene, encoding a DNA methyltransferase thought to function in de novo methylation, is deleted. This gene may play a significant role in leukemic process. In addition, many genes contained on the entire short arm of chromosome 20 are lost in this anomaly and could explain the aggressiveness of ider(20q).

In ider(20q), proximal and distal retained chromosomal regions on the long arm of chromosome 20 are duplicated. Amplification of retained oncogenes such as $H C K$, TNFRSF6B, and DIDO genes is also suggested to explain the worse prognosis of ider(20q) compared to $\operatorname{del}(20 q)$, although this remains controversial [6].

In PMF, cytogenetic analysis is often difficult because of limited bone marrow aspirate and hypocellularity. Thus, the incidence of ider(20q) could be underestimated in myelofibrosis. Furthermore, the heterogeneity of the chromosomal aberrations identified in PMF prevents us from assessing the clinical impact of these abnormalities.

\section{References}

1. GFCH (2004) Recommandations pour la prise en charge cytogénétique des syndromes myéloprolifératifs autres que la leucémie myéloïde chronique (LMC) établies par le Groupe Français de Cytogénétique Hématologique (GFCH). Pathol Biol 52:241-244. doi:10.1016/j.patbio.2004.04.003

2. Li T, Xue Y, Wu Y, Pan J (2004) Clinical and molecular cytogenetic studies in seven patients with myeloid diseases characterized by $\mathrm{i}(20 \mathrm{q}-)$. Br J Haematol 125:337-342. doi:10.1111/j.1365-2141.2004.04921.x

3. Saunders K, Czepulkowski B, Sivalingam R, Hayes JPLA, Aldouri M, Sekhar M, Cummins M, Ho A, Mufti GJ (2005) Isochromosome of a deleted 20q: a rare but recurrent chromosome abnormality in myelodysplastic syndromes. Cancer Genet Cytogenet 156:154-157. doi:10.1016/j.cancergencyto.2004.03.018

4. Lim TH, Lim AS, Tien SL (2006) A novel isoderivative chromosome 20 in a patient with chronic myelomonocytic leukemia. Cancer Genet Cytogenet 170:80-82. doi:10.1016/j. cancergencyto.2006.04.005

5. Shetty S, Roland B (2008) Isoderivative chromosome 20 in bone marrow: three new cases. Cancer Genet Cytogenet 184:72-73. doi:10.1016/j.cancergencyto.2008.03.003

6. Douet-Guilbert N, Lai JL, Basinko A, Gueganic N, Andrieux J, Pollet B, Plantier I, Delattre C, Crepin O, Corm S, Le Bris MJ, Morel F, De Braekeleer M (2008) Fluorescence in situ hybridization characterization of ider(20q) in myelodysplastic syndrome. $\mathrm{Br}$ J Haematol 143:716-720. doi:10.1111/j.1365-2141.2008.07436.x

7. Reilly JT, Snowden JA, Spearing RL, Fitzgerald PM, Jones N, Watmore A, Potter A (1997) Cytogenetic abnormalities and prognostic significance in idiopathic myelofibrosis: a study of 106 cases. Br J Haematol 98:96-102. doi:10.1046/j.1365-2141.1997. 1722990.x

8. Douet-Guilbert N, Basinko A, Morel F, Le Bris MJ, Ugo V, Morice P, Berthou C, De Braekeleer M (2008) Chromosome 20 deletions in myelodysplastic syndromes and Philadelphia-chromosome-negative myeloproliferative disorders: characterization by molecular cytogenetics of commonly deleted and retained regions. Ann Hematol 87:537-544. doi:10.1007/s00277-008-0462-3 